\title{
Payments, Promotion, and the Purple Pill
}

\author{
David B. Ridley*
}

March 5, 2013

\begin{abstract}
Understanding competition in the U.S. drug market requires knowing how sensitive demand is to prices. The relevant prices for insured consumers are copayments. There are many studies of copayment elasticity in the health literature, but they are of limited applicability for studies of competition. Due to a paucity of data, such studies typically control for neither competitor copayment nor advertising. Whereas previous studies examined copayment sensitivity when copayments for branded drugs move in unison, this study examines copayment sensitivity when copayments diverge. This study uses unique panel data of insurance copayments and utilization for 77 insurance groups, as well as data on advertising. The results indicate that demand can be much more sensitive to copayment than previously recognized. Manufacturers selling drugs with higher copayments than branded competitors can lose substantial market share. Manufacturers can offset the loss of demand by increasing advertising to physicians, but it is costly.
\end{abstract}

JEL Classification: I10; L65

Key Words: pharmaceutical; drug; elasticity; price; copayment; advertising

${ }^{*}$ Correspondence to: Fuqua School of Business, Duke University, Durham, NC, USA. E-mail: david.ridley@duke.edu. The author thanks Thomas Abbott, Peter Arcidiacono, Ashish Arora, Ernst Berndt, Jonas Daugherty, Preyas Desai, Richard Frank, Wagner Kamakura, seminar participants at Duke University, the University of Florida, the University of Memphis, the University of Missouri, the University of North Carolina, the Annual Health Economics Conference, International Health Economics Association conference, Southern Economic Association conference, and Western Economic Association International conference. GlaxoSmithKline provided some of the data. Michael Anderson and Hector Rincon provided excellent research assistance. This is the preliminary version of Ridley, D. B. (2013), Payments, Promotion, and the Purple Pill. Health Economics. The final version can be found at http://onlinelibrary.wiley.com/doi/10.1002/hec.3005/abstract 


\section{Introduction}

The U.S. drug market differs from drug markets in other affluent countries, in part because private drug insurance is pervasive. Private insurers even administer the U.S. government drug insurance program for seniors (Ketcham and Simon, 2008). Private insurers use tiered copayments, so patients pay higher copayments for drugs on higher tiers. Drug manufacturers selling in the U.S. also advertise extensively, albeit with mixed success (Bradford et al., 2006).

Comprehending competition in the U.S. drug market requires one to understand how sensitive demand is to copayment and advertising 1 There are many studies of copayment elasticity in the health literature, but these are of limited applicability for studies of branded drug competition because they do not hold competitor copayments constant. Previous studies of copayment elasticity should be viewed as estimates of copayment elasticity when all copayments move together for a given consumer. That measure is useful, because insurers often move copayments in this way. When all copayments move together, mean demand elasticity is -0.2 (and mean standard error is 0.026), according to a meta-analysis by Gemmill et al. (2007). This elasticity of -0.2 appears to hold for a broad definition of health care,including hospital and clinic services, as well as drugs, in a seminal study of copayment elasticity (Manning et al., 1987) $\mathrm{L}^{2}$

Previous studies did not hold competitor copayment constant due to a paucity of data. For example, Leibowitz et al. (1985), one of the drug demand elasticity studies surveyed by Gemmill et al. (2007), wrote that they could not estimate cross copayment elasticity because coinsurance was the same across products $3^{3}$

\footnotetext{
${ }^{1}$ The copayment is the amount paid by the consumer with the remainder of the price paid by the insurer.

${ }^{2}$ Previous studies estimated copayment elasticity of demand. Demand is less elastic when patients and providers have learned that the product works for them (Crawford and Shum, 2005) or if the product is for chronically ill patients (Goldman et al. 2004). Lowering copayments for chronically ill patients increases utilization, but can reduce overall health care costs (Chernew et al. 2008). Demand is less sensitive to copayment (where, for example, patients pay $\$ 10$ ) than to coinsurance (where, for example, patients pay $10 \%$ ) even if the ultimate payment is the same (Dor and Encinosa, 2010). When insurers attempt to steer utilization toward one drug in a class over another, utilization of all drugs in the class can fall (Ridley and Axelsen, 2006 Lee et al., 2012).

${ }^{3}$ Although there has been a dearth of studies of cross-copayment elasticity between branded drugs, there are several studies of cross-copayment elasticity between different types of health care services (Baicker and Goldman, 2011). Furthermore, some studies have examined the effect of competition on national sales (Berndt et al., 1995). Lichtenberg and Philipson (2002) analyzed sales as a function of entry and found that competition between different branded drugs (different molecules) reduced sales more than competition between the branded drug and its generic (same molecules). Also using sales data, Jena et al. (2009) found little competition between the branded drug and other generics (different molecules) from the same class. These studies indicate that there may be competition
} 
In contrast to the previous literature, this study estimates copayment elasticity while controlling for competitor copayment. This study takes a log-linear model of demand (which is typical in the copayment elasticity literature) and adds measures of competitor copayment and advertising. By starting with the standard model, it is possible to show how the inclusion of competitor copayment changes the results. This study finds that when controlling for competitor copayment, demand elasticity is near unity. The evidence here is that demand can be much more sensitive to copayment and competitor copayment than previously realized.

Having established that demand can be highly sensitive to copayment, the next strategic question for the manufacturer is whether it can offset a loss in sales by increasing advertising. This study finds that increases in advertising to physicians (known as "detailing") can offset higher copayments, but it is quite costly. For example, to offset a copayment increase from $\$ 15$ to $\$ 30$, a manufacturer must increase detailing in the short term by nearly 50 percent.

It is rather unique to control for advertising in a study of copayment elasticity, because the data sources are separate and costly. Only two other studies use data on both copayments and advertising, and both focused on direct-to-consumer advertising. Neither of the other two studies estimated copayment or cross-copayment elasticity, which is this studys focus. Donohue et al. (2004) found that direct-to-consumer advertising was positively associated with starting medication and using it for the appropriate duration. Likewise, Wosinska (2002) found evidence that advertising to providers and, to a lesser extent, advertising to consumers, increased demand $4^{4}$

Because copayment and advertising are potentially correlated with unobserved product quality, this study uses both fixed effects (for drug and insurance groups) and instrumental variables (for

between branded drugs, but the studies used national sales and price data, not copayment data. While prices net of rebates surely influence insurance copayments, rebates are generally secret, so the list price (gross of rebates) and copayment might be only weakly correlated.

${ }_{4}^{4}$ Arcidiacono et al. (2013) build on this study by estimating the welfare effects of me-too drugs. Other studies examined advertising but did not examine copayments. Joseph and Mantrala (2009), and Ching and Ishihara (2012) explored the persuasive and informative effects of advertising. Azoulay (2002), Venkataraman and Stremersch (2007), and Ching and Ishihara (2010) examined the relationship between new clinical evidence and the effectiveness of advertising. Ling et al. (2002) estimated the impact of detailing and direct-to-consumer advertising on demand in the prescription and over-the-counter markets. Several other studies analyzed the effect of advertising on drug prescriptions and sales (Neslin, 2001, Rosenthal et al., 2003, Iizuka and Jin, 2005, Bradford et al. |2006, |lizuka and Jin, 2007). Finally, several studies found evidence that detailing affects price sensitivity(Rizzo, 1999, Gönül et al., 2001; Windmeijer et al. 2006). Again, these studies differ from the current analysis in that they focused on advertising and did not use data on copayments. 
copayments and advertising). One instrumental variable is the sales of other drugs by the manufacturer and the total number of other drugs under patent by that manufacturer. The study shows that larger firms have lower copayments. This is useful for the estimation of elasticity because it predicts changes in copayment over time and across manufacturers. For example, if a firm launches a new product, its copayment for other products might decrease because of the increased leverage with insurers. Hence, a copayment might change even if competition and product characteristics are unchanged. The relationship between firm size and copayments is also interesting. If larger

firms have more leverage in negotiating copayments with insurers, then recent mergers could lead to lower copayments for merged manufacturers. While not the focus of this study, it is another interesting implication.

The results of this study are not only important for drug manufacturers, but also for insurers and policy makers. The results show that demand can be highly sensitive to relative copayments, so private insurers can use differential copayment tiers to extract lower prices from manufacturers. Furthermore, the results show that branded substitutes can provide competition in pharmaceutical markets. Previously it was assumed that branded substitutes provided little competition due to patent protection and insurance coverage (Angell, 2000), but this study shows that there is the potential for competition because demand is highly sensitive to copayments and competitor copayments.

The paper is organized as follows. In each section, subsection 1 concerns copayments and subsection 2 concerns advertising. Hence, for copayments, subsection 2.1 concerns methods, 3.1 concerns data, 4.1 concerns results, and 5.1 is the discussion. Similarly, for advertising, subsection 2.2 concerns methods, 3.2 concerns data, 4.2 concerns results, and 5.2 is the discussion.

\section{Methods}

Demand depends on copayment $C$ and advertising $A$ for product $i$ and its competitor $j$ in insurance group $g$ at time $t$. Demand also depends on unobserved product characteristics $\delta$, insurance group characteristics $\gamma$, and a time trend $\tau$. 


$$
Q_{i g t}=Q_{i g t}\left(C_{i g t}, C_{j g t}, A_{i t}, A_{j t}, \delta_{i}, \gamma_{g}, \tau_{t}\right)
$$

The products are substitutes, so increases in own copayment and decreases in competitor copayment are expected to decrease quantity demanded $\left(\partial Q_{i g t} / \partial C_{i g t}<0\right.$ and $\left.\partial Q_{i g t} / \partial C_{j g t}>0\right)$. Increases in own advertising should increase quantity demanded $\left(\partial Q_{i g t} / \partial A_{i t}>0\right)$. The effect of competitor advertising is ambiguous, because competitor advertising can increase overall demand (constructive) or steal demand (combative) (Berndt et al., 1995).

Copayment depends on the price $P_{i t}$, rebate to a particular insurance group $R_{i g t}$, product characteristics $\delta_{i}$, and insurance group characteristics $\gamma_{g}$.

$$
C_{i g t}=C_{i g t}\left(P_{i t}, R_{i g t}, \delta_{i}, \gamma_{g}, \tau_{t}\right)
$$

Drugs with lower prices tend to have lower copayments $\left(\partial C_{i g t} / \partial P_{i t}>0\right)$, because the insurer wants to steer patients toward those drugs and because the insurer can use the threat of a higher copayment to extract lower prices (net of rebates) (Wroblewski, 2005). According to an article in Pharmaceutical Executive, when medical directors of insurance companies "ranked their top criteria for evaluating new drugs for formulary inclusion, cost and efficacy were tied as priority considerations, with safety next on the list....When products are clinically comparable, financial factors are weighted heavily" (Febbo, 2005). However, the correlation between copayment and price might be weak if rebates are large and variable.

Copayment also depends on drug characteristics $\left(\delta_{i}\right)$. We expect copayment to be lower for higher-quality products and for products sold by manufacturers with many other products (because of better negotiating power for the manufacturers). Finally, copayment depends on insurance group characteristics $\left(\gamma_{g}\right) !^{5}$ We expect a lower copayment for insurers providing insurance for businesses in tighter labor markets.

How do consumers find substitutes with lower copayments? According to an article in Phar-

\footnotetext{
${ }^{5}$ The focus of this study is on insurance provided by employers, which is how most Americans obtain their insurance. In many cases, we can think of the employer as making the decisions for the insurer. Drug insurance is often administered by a pharmacy benefit manager.
} 
maceutical Executive,

When consumers feel the pinch of higher-priced treatments, they are likely to request lower-priced products. In a common scenario, a doctor calls in a prescription. The patient arrives at the pharmacy to pick up the medicine and discovers that it is not on the top tier of his insurance formulary. Typically, the co-pay is very high, perhaps more than $\$ 50$. The patient reacts by asking, 'Isn’t there something else you can give me that costs less?'(Seman, 2003)

The pharmacist can inform the patient of a substitute with a lower copayment and call the physician to ask to switch the drug. Sometimes the physician is aware in advance of which products have lower copayments. The aforementioned article cites a Cap Gemini study that found that most physicians surveyed went on-line to check drug copayments. In addition to going on-line, physicians find out about copayments from drug representatives or from letters from insurers.

Based on equation 1, the following log-linear demand function is estimated ${ }^{6}$ The dependent variable is $\ln Q_{i g t}$, the log of the units of $\operatorname{drug} i$ per 10,000 enrollees in insurance group $g$ in month $t$.

$$
\begin{aligned}
\ln Q_{i g t}= & \beta_{0}+\beta_{1} \ln C_{i g t}+\beta_{2} \ln \hat{C}_{g t}+\beta_{3} \ln A_{i t} \\
& +\beta_{4} \ln \sum_{j \neq i} A_{j t}+\delta_{i}+\gamma_{g}+\tau_{t}+\tau_{t}^{2}+\varepsilon_{i g t}
\end{aligned}
$$

Own copayment is $C_{i g t}$ and competitor copayment is the maximum copayment for the insurance group $\hat{C}_{g t}$. In another specification, both the minimum and maximum are used (Table V). The demand model includes fixed effects for the drug $\delta_{i}$ and insurance group $\gamma_{g}$, as well as a time trend $\tau_{t}$ and its square.7 In a robustness check, the drug fixed effect is interacted with the insurance group fixed effect to account for across-group differences in demand (Table IV). The drug fixed effects control for product characteristics that do not vary with time. Product characteristics do

\footnotetext{
${ }^{6}$ All variables transformed to logs are increased by one, because some values would otherwise be zero.

${ }^{7}$ The model includes indicator variables for the availability of Nexium, which was launched after the start of the sample period. Insurance data are not available for Nexium, but advertising data are available, so the analysis controls for the effects of Nexium on the four incumbents using advertising data as well as an indicator variable.
} 
not appear to have changed over time. As described in Section 3.5, both data from IMS Health and the market share plots in Figure 1 indicate that no important information was released during the sample period.

\subsection{Copayment Elasticity Calculation}

There are two copayment elasticities of interest: own copayment elasticity and cross-copayment elasticity. The own copayment elasticity measures how the quantity demanded responds when a drug's copayment changes, holding all else constant. For example, we might be interested in how the quantity demanded responds when a drug moves from tier 2 , with copayment $\$ 30$, to tier 3 , with copayment $\$ 50$. The own copayment is the coefficient on $\log$ of own copayment $\left(\ln C_{i g t}\right)$. (The elasticity is the coefficient because both quantity and copayment are measured in logs.)

The other copayment elasticity measure of interest is how demand changes when other copayments are not constant. For example, we might be interested in how the quantity demanded responds when a drug is on tier 3 and the copayment for tier 3 rises to $\$ 60$. We expect demand to be less elastic in this case, because copayments for tier 3 competitors are rising as well. The elasticity allowing competitors' copayments to move with own copayment is found by adding the coefficient on the log of own copayment $\left(\ln C_{i g t}\right)$ to the coefficient on the log of competitor copayment $\left(\ln \hat{C}_{g t}\right)$.

\subsection{Advertising Depreciation}

Advertising has a cumulative effect on demand, so advertising $A_{i t}$ for drug $i$ at time $t$ is treated as an asset that depreciates:

$$
A_{i t}=(1-\rho) A_{i(t-1)}+F_{i t}=\sum_{v=0}^{t}(1-\rho)^{v} F_{i(t-v)}
$$

where $F_{i t}$ is the flow of new promotional activity and $\rho$ is the monthly depreciation rate. The vector $A_{i t}$ is the stock of the following advertising activities: detailing, direct-to-consumer advertising, medical journal advertising, and the intensity of free sampling. Sampling intensity is the dollar value of samples divided by the dollar value of details. Sampling intensity is used rather than the dollar value of samples, because pharmaceutical sales representatives typically detail physicians and 
A. Advertising stock nationally

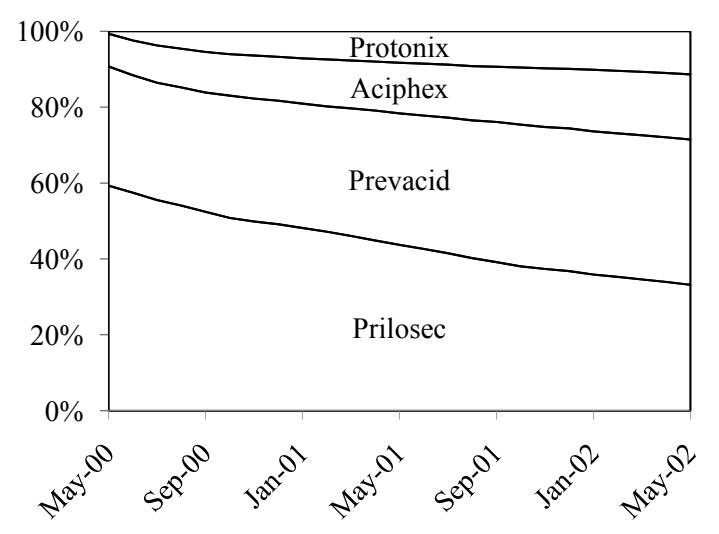

C. Prescription share in largest plan Copayments are constant

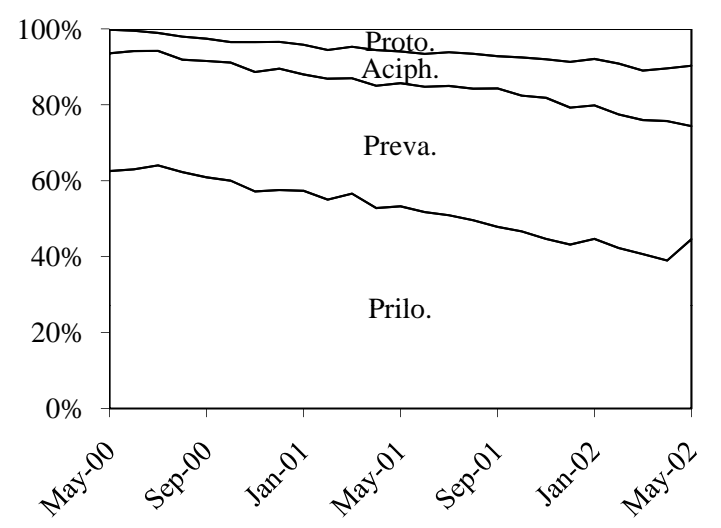

B. Prescription share nationally

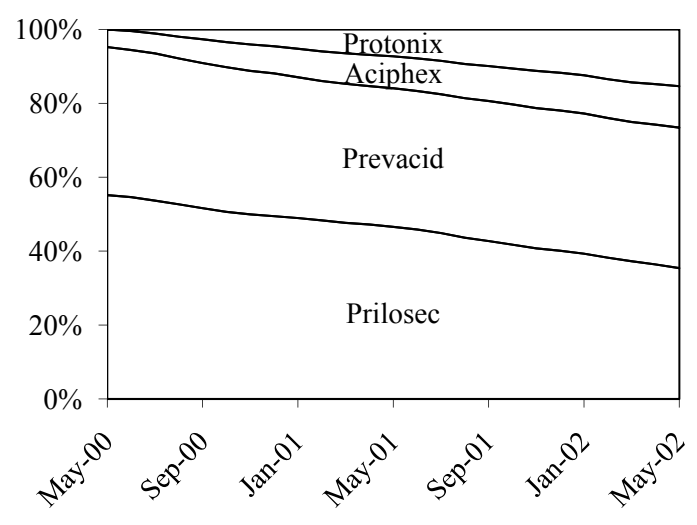

D. Prescription share in smaller plan Copayments are $\$ 10-\$ 30$

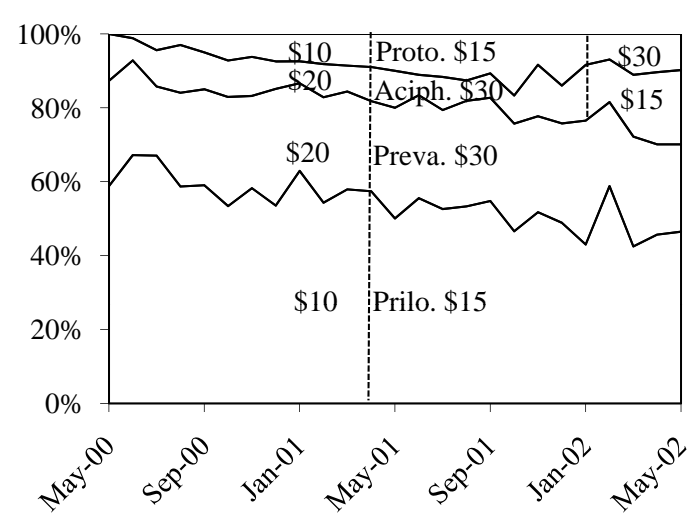

Figure 1: The anti-ulcer drug market in the United States (A and B) and in two of the 77 insurance groups in the sample $(\mathrm{C}$ and $\mathrm{D})$.

provide free samples simultaneously. Advertising by competitors other than $\operatorname{drug} i$ is $\sum_{j \neq i} A_{j t}$.

Depreciation rates are estimated using a four-dimensional grid search. The preferred model is the combination of the depreciation rates and the remaining parameters that provides the best fit. This approach is similar to Berndt et al. (1995) and Ling et al. (2002). 


\subsection{Identification of the Effects of Own Copayment and Advertising}

The manufacturer influences demand directly through advertising (Equation 1) and indirectly through the effect of the price and rebate on the copayment (Equation 2). Both demand and copayment depend on product and insurance group characteristics. This raises concerns about endogeneity. Fixed effects are used to account for the effects of product and insurance group characteristics. Instrumental variables are used to account for the endogeneity of copayment and advertising.

The instrumental variables and definitions are listed in Table I. The first four instruments are specific to the manufacturer and involve manufacturer resources. The manufacturer's sales other than the drug in question, number of product launches net of product patent expirations, detailing for other products, and exchange rate in the country of headquarters are potentially correlated with both copayment and advertising, but they do not belong in the explanatory equation. For example, if a manufacturer has more products and higher sales of products (other than for the drug in question), the manufacturer might have more bargaining power with the insurer. If so, increases in sales and new launches should result in lower copayments. Furthermore, a manufacturer with more products, higher sales of other products, and a more favorable exchange rate might have more resources available for advertising. Also, detailing of other products can affect detailing of the focal product.

Other instruments are included that do not vary by manufacturer but do vary over time. These include the mean hourly earnings for pharmaceutical workers and advertising workers. Also included are the producer price indexes for journal advertising, cable television advertising, sales, pharmaceuticals, intermediate goods, and gasoline. These factors affect supply but not demand.

\subsection{Identification of the Effects of Competitor Copayments}

Competitor copayment might depend on unobserved factors that are correlated with the error term. Fortunately, the way in which insurers set copayment tiers across all drugs provides an exogenous source of variation in competitor copayments. Insurance groups set the formulary tiers independently from a drug. For example, an insurer sets generic copayments at $\$ 10$, preferred 
branded copayments at $\$ 30$, and non-preferred branded copayments at $\$ 50$. Then the insurer assigns drugs to these copayment tiers. The minimum and maximum branded copayment tiers for the insurance group are therefore exogenous to drug characteristics and a useful proxy for competitor copayment. Hence, in the empirical model, demand is estimated as a function of minimum and maximum copayment tiers.

Another advantage of this approach is that it facilitates comparison with the previous literature on copayment elasticity. The model starts with the standard model from the copayment

elasticity literature, adds a measure of competitor copayment, and shows how including competitor copayment changes the results.

Rather than making demand for one drug a function of copayments for all drugs, this model includes three copayments (own, minimum, and maximum) or two copayments (own and maximum). An alternative would be including all competitor copayments, but this would introduce endogeneity problems for the competitor copayments, because the assignment of a competitor drug to a copayment tier would be endogenous to unobserved characteristics. Furthermore, this specification would create problems with collinearity because many copayments are the same. For example, there are only two branded copayments in a class of four drugs.

In summary, the identification strategy uses the structure of copayment tiers (for competitor copayment), instrumental variables (for copayment and advertising), rich variation in copayments (described in Section 3.3), and fixed effects.

\section{Data}

The data include monthly observations for copayments and advertising for branded proton pump inhibitors. The insurance data include copayments and utilization for 25 months (May through May) between 2000 and 2002. The advertising data span 1990 to 2002 and include detailing, free samples, direct-to-consumer, and medical journal advertising.

As in Berndt et al. (1995), Ling et al. (2002), and Berndt et al. (2003) this study focuses on antiulcer drugs. The anti-ulcer drugs studied are proton pump inhibitors. Proton pump inhibitors were the highest selling drug class in the world, and Prilosec (the original "purple pill") and Prevacid 
were both in the top ten in world drug sales during the sample period (Gury, 2003). Proton pump inhibitors are close clinical substitutes for one another.

Proton pump inhibitors directly inhibit the action of the proton acid pump in the gastric lining of the stomach. They are considered an advance in acid control over older treatments such as $H_{2}$ receptor antagonists, which act indirectly by inhibiting gastric acid through blocking histamine receptors on acid-secreting cells in the stomach lining.

The first proton pump inhibitor was Prilosec, which launched in October 1989 (originally under the name "Losec"). Later entrants were Prevacid in May 1995, Aciphex in August 1999, and Protonix in April 2000. Prilosec's manufacturer launched Nexium in March 2001 and hoped to switch consumers to this new product that had longer patent life for its manufacturer and arguably better healing for its patients (Kahrilas et al., 2000). The first proton pump inhibitor facing generic competition was Prilosec in December 2002. Hence, during the sample period, there were neither generic nor over-the-counter proton pump inhibitors available in the United States.

The sample includes the following proton pump inhibitors and dosage strengths: Aciphex 20MG tablet, Prevacid 30MG capsule, Prilosec 40MG capsule, and Protonix 40MG tablet. There are alternative dosage strengths but the aforementioned dosages accounted for at least 82 percent of each brand's sales in any month in the data 8

\subsection{Copayment Data}

The copayment data include copayment and utilization for 25 months for four drugs in 77 insurance groups. The copayment data cover approximately three million people between 2000 and 2002 and are nationally representative. All 77 insurance groups are administered by the same pharmacy benefit manager, AdvancePCS, which also provided the data. AdvancePCS stores only the most recent 25 months of data in its warehouse. The data extend from May 2000 through May 2002. The anti-ulcer drug class was chosen for this period because it was a top-selling class and had no generic versions, thus facilitating analysis of branded competition.

\footnotetext{
${ }^{8}$ In the sample, Aciphex 20MG tablets accounted for 100 percent of Aciphex sales in any month, Prevacid 30MG capsules accounted for at least 82 percent of Prevacid sales in any month, Prilosec 40MG capsules accounted for at least 90 percent of Prilosec sales in any month, and Protonix 40MG tablet accounted for at least 99 percent of Protonix sales in any month.
} 
The sample appears to be highly representative. First, average copayments for the sample match average copayments nationally. According to a survey of U.S. employers, in 2002 the average tier 2 copayment was $\$ 18$ and the average tier 3 copayment was $\$ 32$, conditional on having three tiers Kaiser Family Foundation, 2010). In the sample, the average is identical for tier 2 and only $\$ 1$ greater for tier 3. Second, average market shares across insurance groups in the sample match market shares nationally. Average market shares from the insurance data differ from the national data by no more than one percentage point (Table II). The market shares for the first four drugs in the class are $Q S H A R E_{i g t}$ and $U S S H A R E_{i t}$, where $Q S H A R E_{i g t}$ is the market share in the 77 insurance groups in the sample and $U S S H A R E_{i t}$ is the national market share for insured and uninsured people. Finally, AdvancePCS reports that its own analysis shows that its data closely match United States Census Bureau estimates of the distribution of the U.S. population based on age, sex, and geographic region.

Table [ also illustrates how copayment differs from price. Copayment is the insured patient's monthly out-of-pocket cost for a drug. For example, the average monthly copayment for Prilosec is about $\$ 14$ (with a minimum copayment of $\$ 0$ and a maximum copayment of $\$ 40$ ). Copayment is an important covariant in the demand model. On the other hand, price is calculated by dividing national sales by units or prescriptions. The price includes volume discounts but not negotiated rebates. The price per unit is used to value the free samples, while the price per prescription is used to compare to copayment. For example, the price for Prilosec $40 \mathrm{MG}$ in the sample period is $\$ 106$ per prescription or $\$ 3.53$ per unit. 9

Insurance groups are dropped if they have drugs that cannot be assigned a copayment, if they have no sales of any brand in a month, if their enrollment is below 1000, or if they experience large changes in enrollment. At the midpoint (April 2001) of the original data, there were 123 groups covering 3.9 million members. In the sample used in the paper, there are 77 groups covering 2.6 million members.

In insurance markets, consumers might select an insurance group based on health status or copayment. To control for characteristics that do not vary with time, insurance group fixed effects

\footnotetext{
${ }^{9}$ The average prescription for proton pump inhibitors is 30 units.
} 
are included in the regression (and later interacted with drug fixed effects in the robustness check). However, there might be characteristics that vary with time. Consumers might select different drug insurance based on drug copayment changes. There is evidence that consumers in the insurance groups in the sample could not, would not, and did not switch insurance groups. First, there is evidence that consumers could not switch groups. All of the consumers in this study received their health insurance from a pharmacy benefit manager, not from a more comprehensive health insurer. Although the employer names are blinded from the researchers, employers that use a pharmacy benefit manager regularly carve out that benefit. That is, all employees have the same pharmacy benefit manager with the same terms, regardless of the medical benefit. For example, the author of this paper has a choice of medical benefit: ${ }^{10}$ (for example, Aetna or Blue Cross Blue Shield) but not drug benefits (the pharmacy benefit manager Medco is carved out for all employees). Thus, even if the author changes from Blue Cross Blue Shield to Aetna, the drug benefit would remain the same. Hence, there is evidence that consumers could not switch. Second, there is evidence from Medicare that consumers would not switch even if given the opportunity. Under the Medicare drug benefit consumers have a choice of insurance groups with very different formularies and the opportunity to change each year. However, only 7 percent of Medicare beneficiaries switch (Galewitz, 2009). So even when consumers can change, they rarely do. Third, there is evidence that consumers in the sample did not change insurance groups. Group enrollment was checked before and after copayment changes. Groups with copayment increases did not experience substantial changes in enrollment. For example, 17 insurance groups had copayment changes in January 2001, but total enrollment for those groups changed by less than one percent in that month, an amount comparable to months with no copayment changes. If, despite these checks, consumers were switching insurance groups when copayments increased, then this study would underestimate sensitivity to copayments. This would strengthen the paper's conclusions that demand is more elastic than previously estimated.

\footnotetext{
${ }^{10}$ Medical benefits cover services such as in-patient (hospital) and out-patient (clinic) visits.
} 


\subsection{Advertising Data}

The advertising data consist of monthly observations on promotional spending for anti-ulcer drugs between October 1989 and May 2002. Hence, the data include advertising from the time these products were launched. An observation is a drug-month. Advertising data were provided by Verispan, an independent consulting company that collects data on the pharmaceutical industry. If a given drug is discussed during a sales call, it is considered a detail for that drug. Detail dollars are calculated based on the average cost of a sales call to a provider by a pharmaceutical representative, including the fixed costs of salary and transportation but not variable costs such as samples. Sample dollars are calculated based on the wholesale price of the samples. Direct-to-consumer advertising dollars include spending on newspapers, magazines, radio, television, and billboards. All of the products were advertised to physicians, but only three of the anti-ulcer drugs were advertised to consumers in significant amounts during the sample period.

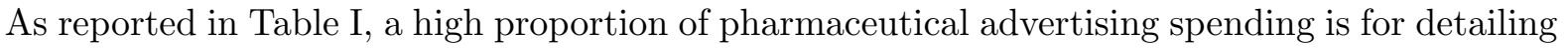
$\left(F D E T A I L_{i t}\right)$ and free samples $\left(F S A M P L E_{i t}\right)$. Drug manufacturers spend millions of dollars each month for their sales forces. The value of the samples is sometimes greater than the cost of the detail representative $\left(F S A M P L E_{i t}>1\right)$, although samples are valued at price rather than at cost to the manufacturer. Whereas millions of dollars are spent each month on detailing and samples, some manufacturers spend relatively little on direct-to-consumer advertising $\left(F D T C_{i t}\right)$ and medical journal advertising ( FJOURNAL $\left.L_{i t}\right)$.

The advertising data include wholesale price, which is the price to wholesalers net of discounts but not net of rebates paid by manufacturers to insurers. These wholesale price data are used for two purposes. First, prices are used to value the samples (as described above). Second, prices are compared to copayments in Table I. Prices are converted from prices per unit to prices per prescription to facilitate the comparison to copayments. To calculate price per prescription, price per unit is multiplied by 30 units per prescription 11

\footnotetext{
${ }^{11}$ The study also uses government data. Data from the U.S. Bureau of Labor Statistics are used to adjust prices for inflation and to estimate costs for the instrumental variables. Data from the Food and Drug Administration are used to calculate net product launches for manufacturers to be used for the instrumental variables.
} 


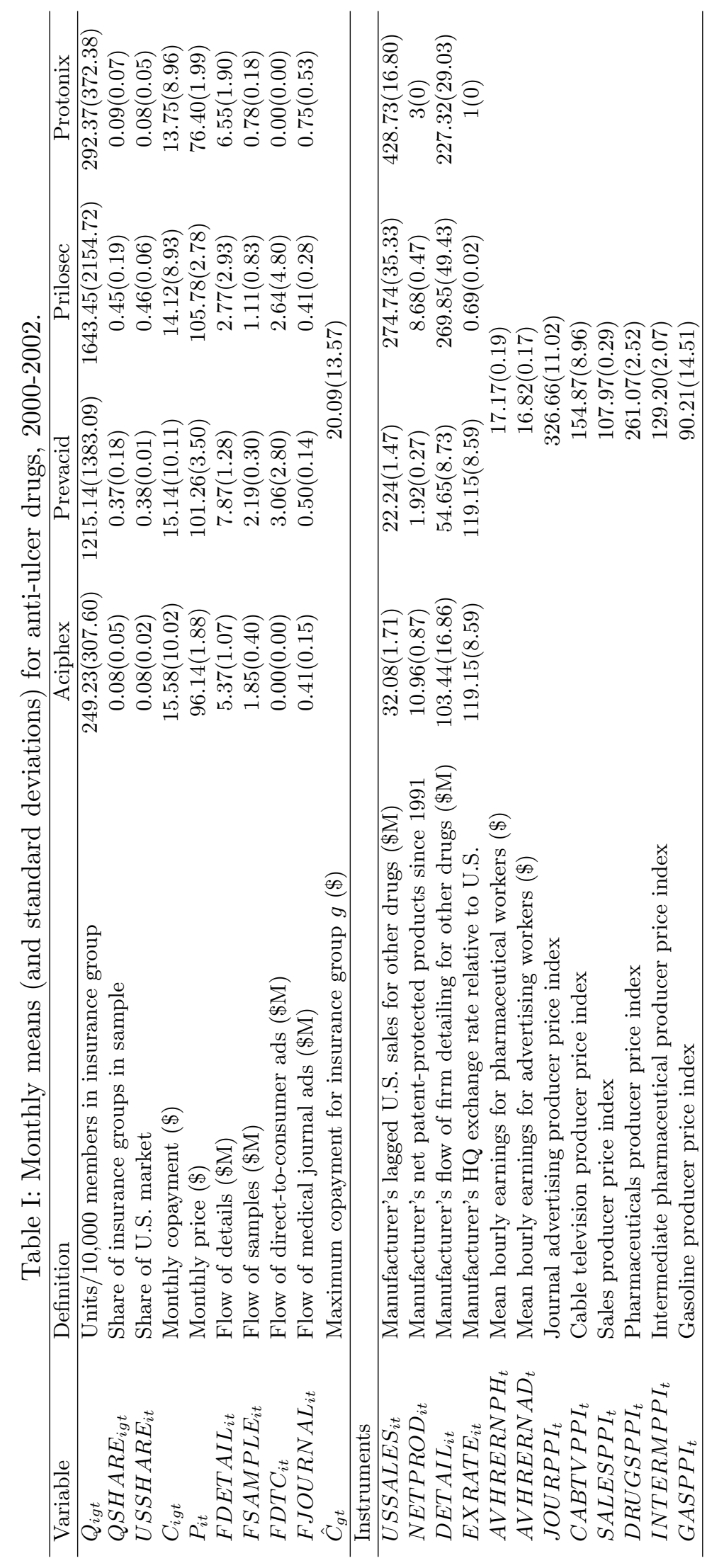




\subsection{Variation in Insurance Data}

The insurance data include variation in copayments over time, across insurance groups, and between drugs in a therapeutic class (with some branded drugs on tier 2 and others on tier 3). There are four drugs, 25 months, and 77 insurance groups. Of the 77 insurance groups, there are 38 with a copayment change. Of these 38 groups, there are nine with copayment changes in multiple months. Copayment changes are typically made on January 1 of 2001 or 2002, but in nine groups the copayment changes are made on days other than January 1 . Within the 38 insurance groups with copayment changes, some changes are both a drug moving between tiers and the copayment changing for the tiers. Other changes involve only a drug changing tiers or a tier changing copayment, as described below.

There are 36 insurance groups in which at least one drug remained on a tier and the copayment for the tier changed. There are 21 insurance groups in which at least one drug changed tiers and the copayment for the tier changed. There are five insurance groups in which the copayment for one tier did not change but the copayment for another tier did change. The aforementioned are not mutually exclusive: one insurance group is included in all three of these changes. That insurance group increased the tier 2 copayment from $\$ 20$ to $\$ 25$ while the tier 3 copayment remained at $\$ 40$.

There are two insurance groups in which copayments are constant for all tiers, but drugs moved between tiers. For example, one insurance group held copayments constant at $\$ 15$ for tier 2 and $\$ 25$ for tier 3. In 2001, anti-ulcer medicines Aciphex and Protonix exchanged tiers. Another group had

drugs change tiers with copayments unchanged. Copayment and market share in that insurance group are illustrated in Figure 1D.

\subsection{Market Share Plots}

Market shares are illustrated in Figure 1. There are four plots of market shares illustrated: advertising (A), United States prescriptions (B), prescriptions in the largest insurance group (which had one copayment tier with no changes) (C), and prescriptions in the insurance group with the largest copayment decrease (which had multiple tiers that changed) (D). Parts C and D illustrate two of the 77 insurance groups, so these are case studies. 
Parts A, B, and C of Figure 1 have similar market shares. For example, in May 2000, Prilosec had 59 percent of cumulative advertising (A), 55 percent of the national prescription market (B), and 58 percent of the prescriptions in the insurance group in which all copayments are the same and unchanged (C). However, when Prilosec had a lower copayment than competitors, it had a higher market share of 67 percent (D). Hence, cumulative advertising (A) appears to be a good predictor of volume when there are no differences in copayments $(\mathrm{C})$. However, when copayments differ across drugs (D), market shares differ.

Likewise, during the last six months of the sample period, Prilosec's advertising share had fallen to $35 \%$ (Figure 1A) and national prescription share had fallen to 32\% (Figure 1B). However, in an insurance group in which Prilosec had the lowest copayment in its class, its prescription share was $48 \%$ (Figure 1D). Hence, a low copayment may prevent prescription share erosion, even when advertising share is eroding.

Figures 1D and 2 illustrate the same insurance group, but whereas Figure 1D shows market shares for all four drugs, Figure 2 shows total prescriptions for only two drugs: Aciphex and Protonix. These drugs are isolated to provide a case study of the effects of copayment changes on demand.

Protonix started with few prescriptions because it launched in May 2000. However, Protonix had a lower copayment than Aciphex and gained prescriptions, overtaking Aciphex. In January 2002, Aciphex was assigned a lower copayment than Protonix and Aciphex gained in prescriptions. In this case study, it appears that demand is quite sensitive to copayment and competitor copayment.

The figures show that a drug's utilization share is rising with its advertising share when copayments are equal, but when copayments differ the cheaper drug is increasing in utilization share.

\subsection{Product Characteristics}

Consumer perceptions of products can change over time, due to factors such as new clinical evidence (Azoulay, 2002; Venkataraman and Stremersch, 2007; Chintagunta et al., 2009, Ching and Ishihara, 2010). However, based on data from IMS Health, it appears that during the sample period the new clinical evidence was minor. In the anti-ulcer market during the sample period, the 


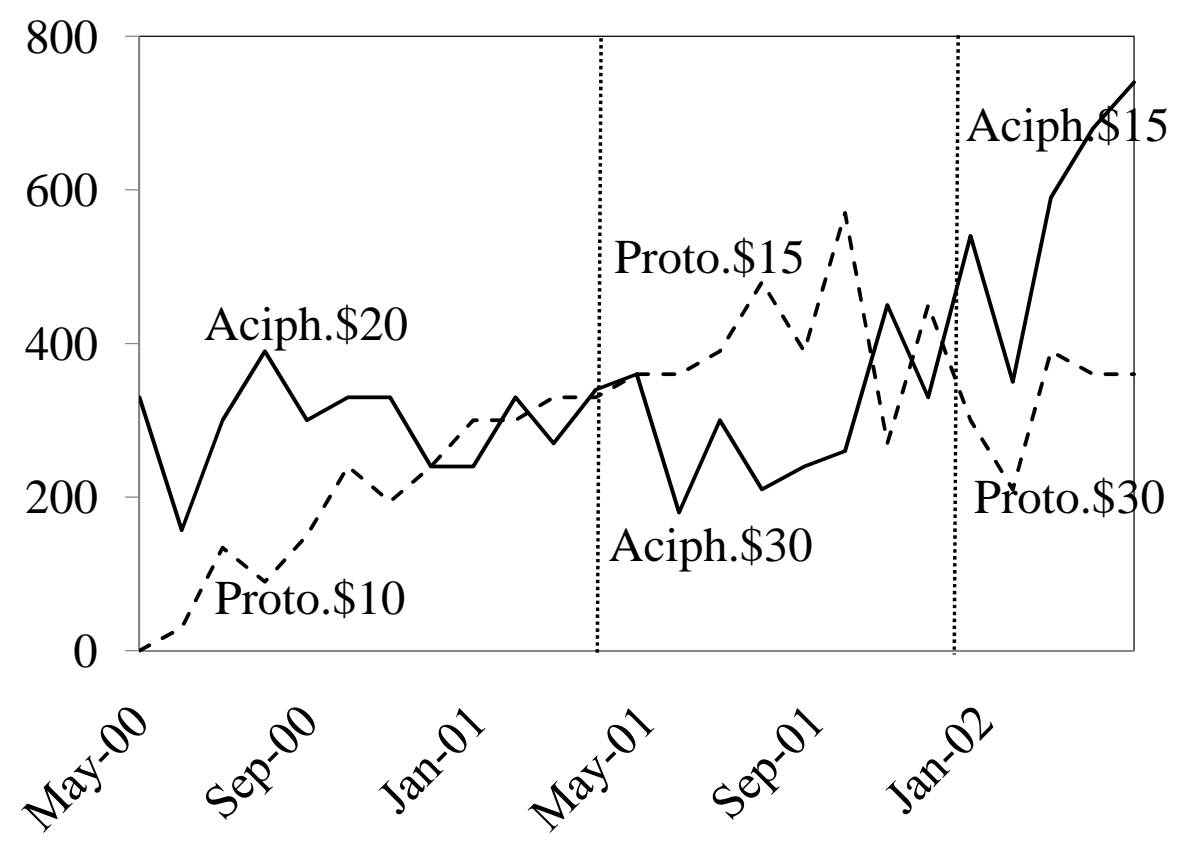

Figure 2: Units per month for two drugs in the insurance group from Figure $1 \mathrm{D}$.

makers of Prevacid filed for new indications for non-ulcer dyspepsia and NSAID-induced ulcers, while the makers of Protonix were approved for the additional indication of long-term treatment of gastroesophageal reflux disease (GERD). Furthermore, there does not appear to have been any shift in national market share, as illustrated in Figure $1 \mathrm{~B}$.

\section{Results}

Regression results appear in Table II]. The regression results from Table II are used to calculate copayment elasticities in Table III. Robustness checks appear in Table IV and Table V. Results from the first stage appear in Table VI. 


\subsection{Results for Copayments}

The regression results using ordinary least squares (OLS) and two-stage least squares (2SLS) are reported in Table II. The coefficient on log monthly copayment is the copayment elasticity when all else is held constant. The sign is negative, as expected, and it is statistically and economically significant. The elasticity is near unity not only in Table II but across four specifications (as summarized in Table III).

The coefficient on log maximum competitor copayment is positive. This dampens the aforementioned effect of own copayment. Hence, if the maximum competitor copayment is rising as own copayment rises, then the effect of own copayment will be smaller. Recall from Section 2.1 that we add own copayment to competitor copayment to calculate the elasticity when they move together. When allowing competitor copayment to vary with own copayment, elasticity is cut in half.12

\subsection{Results for Advertising}

Like the results for copayment, the results for advertising appear in Table II] Detailing has an economically and statistically significant $(p<0.001)$ impact on demand in the anti-ulcer market. The measure of samples is samples per detail, which is negative, indicating that giving more samples on a detail visit can crowd out purchased product. Direct-to-consumer advertising is generally not statistically significant in the analysis. Medical journal advertising appears negative but this might mislead because most medical journal advertising occurs early in a product's life, when the quantity demanded is low. The effect of competitors' advertising on demand for the class is not statistically significant.

Advertising depreciation rates were estimated using a grid search described in Section 2.2 . Depreciation rates for detailing, direct-to-consumer advertising, and medical journal advertising were 0 . Depreciation rates for free samples were 0.5 . These estimates are consistent with Berndt et al. (1995) and Ling et al. (2002).

\footnotetext{
${ }^{12}$ Furthermore, in results available upon request from the author, omitting competitor copayment from the regression produced an anti-ulcer drug elasticity of -0.25 .
} 
Table II: Results. Dependent variable is natural log of units per 10,000 enrollees.

\begin{tabular}{|c|c|c|c|}
\hline Variable & Definition & OLS Ulcer & 2SLS Ulcer \\
\hline $\ln C_{i g t}$ & Log monthly copayment & $\begin{array}{c}-0.84^{* * *} \\
(0.07)\end{array}$ & $\begin{array}{c}-1.11^{\text {*** }} \\
(0.31)\end{array}$ \\
\hline $\ln \hat{C}_{g t}$ & Log maximum competitor copayment & $\begin{array}{c}0.28^{* * *} \\
(0.07)\end{array}$ & $\begin{array}{l}0.60^{*} \\
(0.27)\end{array}$ \\
\hline $\ln D E T A I L_{i t}$ & Log stock details & $\begin{array}{c}2.16^{* * *} \\
(0.28)\end{array}$ & $\begin{array}{c}1.55^{* * *} \\
(0.31)\end{array}$ \\
\hline $\ln S A M P L E_{i t}$ & Log samples/details & $\begin{array}{c}-1.2 \\
(0.82)\end{array}$ & $\begin{array}{l}-2.65^{*} \\
(1.17)\end{array}$ \\
\hline $\ln D T C_{i t}$ & Log stock direct-to-consumer ads & $\begin{array}{l}0.13^{*} \\
(0.06)\end{array}$ & $\begin{array}{l}-0.048 \\
(0.14)\end{array}$ \\
\hline $\ln J O U R N A L_{i t}$ & Log stock medical journal ads & $\begin{array}{c}-0.18^{* * *} \\
(0.03)\end{array}$ & $\begin{array}{c}-0.14^{* * *} \\
(0.03)\end{array}$ \\
\hline $\ln D E T A I L_{j t}$ & Log stock competitor details & $\begin{array}{c}0.95 \\
(1.17)\end{array}$ & $\begin{array}{c}0.58 \\
(1.52)\end{array}$ \\
\hline $\ln S A M P L E_{j t}$ & Log competitor samples/details & $\begin{array}{c}2.45 \\
(1.73)\end{array}$ & $\begin{array}{c}2.33 \\
(1.89)\end{array}$ \\
\hline $\ln D T C_{j t}$ & Log stock competitor direct-to-consumer ads & $\begin{array}{c}0.17 \\
(0.10)\end{array}$ & $\begin{array}{l}-0.041 \\
(0.17)\end{array}$ \\
\hline $\ln J O U R N A L_{j t}$ & Log stock competitor medical journal ads & $\begin{array}{l}-1.23 \\
(0.68)\end{array}$ & $\begin{array}{l}-1.24 \\
(1.03)\end{array}$ \\
\hline$\tau_{t}$ & Time & $\begin{array}{l}0.032 \\
(0.06)\end{array}$ & $\begin{array}{l}0.086 \\
(0.09)\end{array}$ \\
\hline$\tau_{t}^{2}$ & Time squared & $\begin{array}{c}-0.00099 \\
(0.00)\end{array}$ & $\begin{array}{c}-0.0013 \\
(0.00)\end{array}$ \\
\hline$\delta_{i}, \gamma_{g}$ & Drug and insurance group fixed effects & \multicolumn{2}{|c|}{ Included } \\
\hline $\mathrm{N}$ & & 7700 & 7700 \\
\hline$R^{2}$ & & 0.78 & 0.75 \\
\hline J-Stat $p-$ value & & 0.87 & 0.33 \\
\hline C-Stat $p-$ value & & 0.31 & \\
\hline
\end{tabular}

Standard errors in parentheses

${ }^{*} p<0.05,{ }^{* *} p<0.01,{ }^{* * *} p<0.001$

\subsection{Results for the Instrumental Variables}

The C-statistic is used to test whether copayment and advertising are orthogonal to the error term. Hansen's J-statistic is used to test over-identifying restrictions for the excluded instruments. The p-values for the C-statistics reported in Table II indicate that instruments were not needed, but robustness checks indicate that instruments are needed (Tables IV). Given the intuition about copayment and advertising, and the need for instruments in one model, instruments were used in 
Table III: Estimates for copayment elasticity of demand holding constant competitor copayment

\begin{tabular}{lcrc}
\hline Model & Competitor Copay & Table & Own Copay Elasticity \\
\hline 2SLS with fixed effects & Max & II & -1.11 \\
OLS with fixed effects & Max & $\overline{\overline{I I}}$ & -0.84 \\
2SLS with fixed effects interacted & Max & IV & -1.31 \\
2SLS with fixed effects & Max \& Min & V & -0.76 \\
\hline
\end{tabular}

Table IV: Robustness check with drug and insurance group interacted. Dependent variable is natural $\log$ of units per 10,000 enrollees.

\begin{tabular}{|c|c|c|c|}
\hline Variable & Definition & OLS Ulcer & 2SLS Ulcer \\
\hline $\ln C_{i g t}$ & Log monthly copayment & $\begin{array}{r}-0.55^{* *} \\
(0.17)\end{array}$ & $\begin{array}{l}-1.31^{*} \\
(0.63)\end{array}$ \\
\hline $\ln \hat{C}_{g t}$ & Log maximum competitor copayment & $\begin{array}{l}0.063 \\
(0.12)\end{array}$ & $\begin{array}{c}0.76 \\
(0.48)\end{array}$ \\
\hline $\ln D E T A I L_{i t}$ & Log stock details & $\begin{array}{c}2.14^{* * *} \\
(0.18)\end{array}$ & $\begin{array}{c}1.57^{* * *} \\
(0.25)\end{array}$ \\
\hline $\ln S A M P L E_{i t}$ & Log samples/details & $\begin{array}{l}-1.25^{*} \\
(0.57)\end{array}$ & $\begin{array}{c}-2.66^{* *} \\
(0.90)\end{array}$ \\
\hline $\ln D T C_{i t}$ & Log stock direct-to-consumer ads & $\begin{array}{c}0.14^{* *} \\
(0.047)\end{array}$ & $\begin{array}{l}-0.022 \\
(0.13)\end{array}$ \\
\hline $\ln J O U R N A L_{i t}$ & Log stock medical journal ads & $\begin{array}{c}-0.18^{* * *} \\
(0.023)\end{array}$ & $\begin{array}{c}-0.14^{* * *} \\
(0.026)\end{array}$ \\
\hline $\ln D E T A I L_{j t}$ & Log stock competitor details & $\begin{array}{c}0.67 \\
(0.73)\end{array}$ & $\begin{array}{c}0.41 \\
(1.07)\end{array}$ \\
\hline $\ln S A M P L E_{j t}$ & Log competitor samples/details & $\begin{array}{l}2.55^{* *} \\
(0.88)\end{array}$ & $\begin{array}{c}2.44 \\
(1.41)\end{array}$ \\
\hline $\ln D T C_{j t}$ & Log stock competitor direct-to-consumer ads & $\begin{array}{c}0.18^{* *} \\
(0.067)\end{array}$ & $\begin{array}{l}-0.015 \\
(0.14)\end{array}$ \\
\hline $\ln J O U R N A L_{j t}$ & Log stock competitor medical journal ads & $\begin{array}{l}-1.13^{*} \\
(0.44)\end{array}$ & $\begin{array}{l}-1.22 \\
(0.80)\end{array}$ \\
\hline$\tau_{t}$ & Time & $\begin{array}{c}0.034 \\
(0.037)\end{array}$ & $\begin{array}{c}0.086 \\
(0.062)\end{array}$ \\
\hline$\tau_{t}^{2}$ & Time squared & $\begin{array}{l}-0.00093 \\
(0.00051)\end{array}$ & $\begin{array}{c}-0.0013 \\
(0.00087)\end{array}$ \\
\hline$\delta_{i}, \gamma_{g}$ & Drug and insurance group fixed effects & \multicolumn{2}{|c|}{ Included and interacted } \\
\hline$N$ & & 7700 & 7700 \\
\hline$R^{2}$ & & 0.91 & 0.87 \\
\hline J-Stat $p-$ value & & 0.028 & 0.0035 \\
\hline C-Stat $p-$ value & & 0.028 & \\
\hline
\end{tabular}

Standard errors in parentheses

${ }^{*} p<0.05,{ }^{* *} p<0.01,{ }^{* * *} p<0.001$ 
Table V: Robustness check with minimum as well as maximum copayments. Dependent variable is natural $\log$ of units per 10,000 enrollees.

\begin{tabular}{|c|c|c|c|}
\hline Variable & Definition & OLS Ulcer & 2SLS Ulcer \\
\hline $\ln C_{i g t}$ & Log monthly copayment & $\begin{array}{c}-0.88^{* * *} \\
(0.069)\end{array}$ & $\begin{array}{c}-0.76^{* * *} \\
(0.14)\end{array}$ \\
\hline $\ln \underline{\mathrm{C}}_{g t}$ & Log minimum competitor copayment & $\begin{array}{c}0.50^{* * *} \\
(0.12)\end{array}$ & $\begin{array}{c}0.25 \\
(0.17)\end{array}$ \\
\hline $\ln \hat{C}_{g t}$ & Log maximum competitor copayment & $\begin{array}{c}0.028 \\
(0.087)\end{array}$ & $\begin{array}{c}0.18 \\
(0.10)\end{array}$ \\
\hline $\ln D E T A I L_{i t}$ & Log stock details & $\begin{array}{c}2.17^{* * *} \\
(0.28)\end{array}$ & $\begin{array}{c}1.50^{* * *} \\
(0.31)\end{array}$ \\
\hline $\ln S A M P L E_{i t}$ & Log samples/details & $\begin{array}{l}-1.19 \\
(0.82)\end{array}$ & $\begin{array}{l}-2.85^{*} \\
(1.17)\end{array}$ \\
\hline $\ln D T C_{i t}$ & Log stock direct-to-consumer ads & $\begin{array}{c}0.13^{*} \\
(0.061)\end{array}$ & $\begin{array}{l}-0.10 \\
(0.14)\end{array}$ \\
\hline $\ln J O U R N A L_{i t}$ & Log stock medical journal ads & $\begin{array}{c}-0.18^{* * *} \\
(0.028)\end{array}$ & $\begin{array}{c}-0.14^{* * *} \\
(0.032)\end{array}$ \\
\hline $\ln D E T A I L_{j t}$ & Log stock competitor details & $\begin{array}{c}0.95 \\
(1.17)\end{array}$ & $\begin{array}{c}0.75 \\
(1.51)\end{array}$ \\
\hline $\ln S A M P L E_{j t}$ & Log competitor samples/details & $\begin{array}{c}2.46 \\
(1.73)\end{array}$ & $\begin{array}{c}1.85 \\
(1.86)\end{array}$ \\
\hline $\ln D T C_{j t}$ & Log stock competitor direct-to-consumer ads & $\begin{array}{c}0.18 \\
(0.10)\end{array}$ & $\begin{array}{l}-0.085 \\
(0.17)\end{array}$ \\
\hline $\operatorname{lnJOURNAL_{jt}}$ & Log stock competitor medical journal ads & $\begin{array}{l}-1.22 \\
(0.68)\end{array}$ & $\begin{array}{l}-0.99 \\
(1.02)\end{array}$ \\
\hline$\tau_{t}$ & Time & $\begin{array}{c}0.031 \\
(0.062)\end{array}$ & $\begin{array}{c}0.067 \\
(0.086)\end{array}$ \\
\hline$\tau_{t}^{2}$ & Time squared & $\begin{array}{l}-0.00099 \\
(0.00086)\end{array}$ & $\begin{array}{l}-0.0011 \\
(0.0012)\end{array}$ \\
\hline$\delta_{i}, \gamma_{g}$ & Drug and insurance group fixed effects & \multicolumn{2}{|c|}{ Included } \\
\hline $\mathrm{N}$ & & 7700 & 7700 \\
\hline$R^{2}$ & & 0.78 & 0.75 \\
\hline J-Stat $p-$ value & & 0.75 & 0.32 \\
\hline C-Stat $p-$ value & & 0.14 & \\
\hline
\end{tabular}

Standard errors in parentheses

${ }^{*} p<0.05,{ }^{* *} p<0.01,{ }^{* * *} p<0.001$

all models. The p-values for the J-statistics reported in Table II indicate that they passed the overidentification test, meaning that there was sufficient information to test the assumption that the instruments were uncorrelated with the error term.

Table VI contains the results of the first stage. From column 1, there is a negative (although sometimes insignificant) relationship between copayment and the manufacturer's sales of other 
Table VI: First-stage results.

\begin{tabular}{|c|c|c|c|c|c|}
\hline Variable & Log Copay & Log Stock Detail & Log Samples & Log Stock DTC & Log Stock Journal \\
\hline \multirow{2}{*}{$U S S A L E S_{i t}$} & $-0.00040^{*}$ & $-0.0060^{* * *}$ & $0.00087^{* * *}$ & $-0.0057^{* * *}$ & $-0.057^{* * *}$ \\
\hline & $(0.00016)$ & $(0.00017)$ & $(0.000038)$ & $(0.00026)$ & $(0.0015)$ \\
\hline \multirow[t]{2}{*}{$N E T P R O D_{i t}$} & -0.0057 & -0.0063 & $0.019^{* * *}$ & $-0.16^{* * *}$ & $0.24^{* * *}$ \\
\hline & $(0.0047)$ & $(0.0050)$ & $(0.0011)$ & $(0.0076)$ & $(0.043)$ \\
\hline \multirow[t]{2}{*}{$F D E T A I L_{i t}$} & $-0.35^{* * *}$ & $0.30^{* * *}$ & $-0.36^{* * *}$ & $-1.15^{* * *}$ & $2.46^{* *}$ \\
\hline & $(0.085)$ & $(0.092)$ & $(0.020)$ & $(0.14)$ & $(0.78)$ \\
\hline \multirow{2}{*}{$E X R A T E_{i t}$} & 0.00054 & $-0.0083^{* * *}$ & $0.0014^{* * *}$ & $0.0074^{* * *}$ & $0.024^{* * *}$ \\
\hline & $(0.00050)$ & $(0.00054)$ & $(0.00012)$ & $(0.00081)$ & $(0.0046)$ \\
\hline \multirow{2}{*}{$\ln A V H R E R N P H_{t}$} & -0.081 & $-2.92^{* * *}$ & $0.88^{* * *}$ & $-2.79^{* * *}$ & $-8.37^{* * *}$ \\
\hline & $(0.21)$ & $(0.23)$ & $(0.050)$ & $(0.35)$ & $(1.97)$ \\
\hline \multirow[t]{2}{*}{$\ln A V H R E R N A D_{t}$} & 0.24 & $-1.21^{* * *}$ & -0.013 & $2.36^{* * *}$ & $-20.7^{* * *}$ \\
\hline & $(0.25)$ & $(0.27)$ & $(0.058)$ & $(0.40)$ & $(2.27)$ \\
\hline \multirow[t]{2}{*}{$\ln \mathrm{JOURPPI}_{t}$} & -0.29 & $-5.79^{* * *}$ & $1.39^{* * *}$ & $-2.75^{* * *}$ & $-35.0^{* * *}$ \\
\hline & $(0.18)$ & $(0.20)$ & $(0.043)$ & $(0.30)$ & $(1.68)$ \\
\hline \multirow[t]{2}{*}{$\ln C A B T V P P I_{t}$} & 0.0028 & $-0.63^{* * *}$ & $0.034^{* *}$ & $-0.83^{* * *}$ & $-2.64^{* * *}$ \\
\hline & $(0.045)$ & $(0.049)$ & $(0.011)$ & $(0.073)$ & $(0.42)$ \\
\hline \multirow[t]{2}{*}{$\ln S A L E S P P I_{t}$} & 1.88 & $-8.02^{* * *}$ & $0.79^{* *}$ & $-4.20^{*}$ & $-77.9^{* * *}$ \\
\hline & $(1.16)$ & $(1.24)$ & $(0.27)$ & $(1.88)$ & $(10.7)$ \\
\hline \multirow[t]{2}{*}{$\ln D R U G S P P I_{t}$} & 0.38 & $-5.66^{* * *}$ & $0.74^{* * *}$ & $4.86^{* * *}$ & $-28.1^{* * *}$ \\
\hline & $(0.55)$ & $(0.59)$ & $(0.13)$ & $(0.89)$ & $(5.04)$ \\
\hline \multirow[t]{2}{*}{$\ln I N T E R M P P I_{t}$} & $-2.22^{* *}$ & $-12.1^{* * *}$ & $4.15^{* * *}$ & $6.43^{* * *}$ & $-60.7^{* * *}$ \\
\hline & $(0.68)$ & $(0.73)$ & $(0.16)$ & $(1.10)$ & $(6.25)$ \\
\hline \multirow[t]{2}{*}{$\ln G A S P P I_{t}$} & 0.0032 & $0.57^{* * *}$ & $-0.14^{* * *}$ & $0.12^{* * *}$ & $4.73^{* * *}$ \\
\hline & $(0.017)$ & $(0.018)$ & $(0.0040)$ & $(0.028)$ & $(0.16)$ \\
\hline \multirow[t]{2}{*}{$\ln A V G C_{t}$} & $-0.71^{* * *}$ & -0.037 & 0.011 & -0.014 & -0.32 \\
\hline & $(0.030)$ & $(0.033)$ & $(0.0071)$ & $(0.049)$ & $(0.28)$ \\
\hline \multirow[t]{2}{*}{$\ln \hat{C}_{i t}$} & $1.27^{* * *}$ & 0.035 & -0.0099 & 0.010 & 0.27 \\
\hline & $(0.025)$ & $(0.027)$ & $(0.0059)$ & $(0.041)$ & $(0.23)$ \\
\hline \multirow[t]{2}{*}{$\ln D E T_{j t}$} & $0.45^{* *}$ & $0.44^{* *}$ & $-0.11^{* *}$ & $8.10^{* * *}$ & $30.5^{* * *}$ \\
\hline & $(0.15)$ & $(0.16)$ & $(0.035)$ & $(0.24)$ & $(1.38)$ \\
\hline \multirow{2}{*}{$\ln S A M P L E_{j t}$} & 0.15 & $6.35^{* * *}$ & $-1.96^{* * *}$ & $-7.74^{* * *}$ & $26.8^{* * *}$ \\
\hline & $(0.21)$ & $(0.23)$ & $(0.050)$ & $(0.35)$ & $(1.96)$ \\
\hline \multirow[t]{2}{*}{$\ln D T C_{j t}$} & $-0.022^{*}$ & $-0.029^{* *}$ & $-0.0056^{* *}$ & $-1.03^{* * *}$ & $-0.58^{* * *}$ \\
\hline & $(0.0093)$ & $(0.0099)$ & $(0.0022)$ & $(0.015)$ & $(0.085)$ \\
\hline \multirow[t]{2}{*}{$\ln J O U R N_{j t}$} & -0.049 & $-6.05^{* * *}$ & $1.61^{* * *}$ & $2.19^{* * *}$ & $-34.5^{* * *}$ \\
\hline & $(0.055)$ & $(0.059)$ & $(0.013)$ & $(0.090)$ & $(0.51)$ \\
\hline \multirow[t]{2}{*}{$\tau$} & -0.0011 & $0.61^{* * *}$ & $-0.16^{* * *}$ & $-0.29^{* * *}$ & $2.33^{* * *}$ \\
\hline & $(0.0042)$ & $(0.0045)$ & $(0.00098)$ & $(0.0068)$ & $(0.038)$ \\
\hline \multirow[t]{2}{*}{$\tau^{2}$} & $-0.00025^{* *}$ & $-0.0094^{* * *}$ & $0.0025^{* * *}$ & $0.0025^{* * *}$ & $-0.044^{* * *}$ \\
\hline & $(0.000084)$ & $(0.000091)$ & $(0.000020)$ & $(0.00014)$ & $(0.00078)$ \\
\hline $\mathrm{N}$ & 7700 & 7700 & 7700 & 7700 & 7700 \\
\hline$R^{2}$ & 0.99 & 0.98 & 0.94 & 0.99 & 0.66 \\
\hline $\mathrm{F}$ & 11087.6 & 4380.7 & 1267.5 & 187737.3 & 146.2 \\
\hline
\end{tabular}

Standard errors in parentheses

${ }^{*} p<0.05,{ }^{* *} p<0.01,{ }^{* * *} p<0.001$

products and count of other products (USSALES and NETPROD), indicating that the manufacturer has more leverage with insurers when it has more products. Furthermore, for detailing, which is the most important of the advertising variables, seven of the eight cost variables (various 
average hourly earnings and producer price indexes) are the expected (negative) sign.

\section{Discussion}

\subsection{Discussion of Copayments}

When holding competitor copayment tiers constant, elasticity is near unity across four specifications (summarized in Table III). However, elasticity is cut in half when allowing competitor copayment to vary with own copayment.

Proton pump inhibitors are close substitutes for one another, so we expect somewhat higher elasticities than other classes of drugs. Nevertheless, this study finds elasticity estimates that are consistent with previous studies when copayments move together. It is when copayments move apart that the elasticity estimates are considerably different from previous studies. The important difference from previous studies is that other researchers did not have rich data on competing drugs with different copayments.

The elasticity estimates show that when a drug has branded substitutes, its relative copayment can have a considerable effect on demand. For example, using the results from the first specification in Table III (where elasticity is -1.11), if an anti-ulcer drug moves from tier $2 \$ 15$ to tier $3 \$ 30$ (as Protonix does in figures 1D and 21, one would expect utilization for that drug to decrease by about

$74 \%$ (holding advertising constant) ${ }^{13}$ If, on the other hand, the drug remained at tier 3 , with the copayment for tier 3 changing from $\$ 15$ to $\$ 30$, one would expect its utilization to only decrease by about $34 \%$. Hence, a drug's sales are more sensitive to copayment increases when the drug's copayment is rising and competitor copayments are constant or decreasing.

\subsection{Discussion of Advertising}

Detailing has an economically and statistically significant $(p<0.001)$ impact on demand in the anti-ulcer market. Detailing might be used by manufacturers to offset sales lost from higher copayments. Recall the example of the drug that moved from tier $2 \$ 15$ to tier $3 \$ 30$ with a resulting

\footnotetext{
${ }^{13}$ When calculating arc elasticity, the percentage change in copayment is $67 \%$ whether the copayment changes from $\$ 15$ to $\$ 30$ or from $\$ 30$ to $\$ 15$. Multiply $67 \%$ by elasticity -1.11 (from Table III) to get $74 \%$.
} 
decrease in utilization of $74 \%$. Advertising elasticity estimates indicate that the manufacturer might offset this increase in copayment with an increase in detailing of about $48 \%$ in the local market 14 Given that detailing has long-lasting effects, an increase in detailing today can expand demand throughout the year. Sales forces are not, however, easily expanded and contracted.

Detail representatives also give free samples when they visit physician offices. The effect of free samples on demand is ambiguous, though, because free samples can provide access to physicians and raise consumer awareness, but free samples can also crowd out purchased products.

Direct-to-consumer advertising is generally not statistically significant in the analysis. One explanation is that manufacturers were not yet using direct-to-consumer advertising effectively at the time of the sample. Only three years earlier, the Food and Drug Administration loosened restrictions and consumer-oriented advertising increased considerably. Manufacturers were still learning how to effectively use this form of advertising.

Medical journal advertising appears negative, but this might mislead. Manufacturers do most of their medical journal advertising early in a product's life to raise physician awareness of a product's availability. The brand-months with the highest medical journal advertising occurred just after the launch of Protonix and Aciphex. Protonix launched in April. The top four brand-months for advertising were for Protonix in June through September 2000. Next on the list are Aciphex in November and December 1999, shortly after that drug launched in August 1999. Hence, medical journal advertising is positively associated with new products and, thus, low sales. Competitors' medical journal advertising is also negatively associated with demand. Perhaps medical journal advertising hurts competitor demand and helps own demand, though the benefit on own demand is muted by the newness of the product.

The effect of competitors' advertising on demand for the class is not statistically significant. Manufacturers often promote a brand name rather than promoting awareness of a disease class. If manufacturers focused on disease awareness they could expand the market for all competitors. The industry trade group promoted such a strategy. "Companies are encouraged to promote health and disease awareness as part of their direct-to-consumer advertising" (Pharmaceutical Research and

${ }^{14}$ Divide the percentage change in utilization $(74 \%)$ by the coefficient on detailing (1.55) to find the necessary increase in detailing (48\%). 
Manufacturers of America, 2005). "The principles also include refraining from advertisements that merely mention a drug's brand name while staying mum on its purpose and side effects" (Hensley, 2005). If these guidelines are implemented, advertising might expand demand for an entire class of drugs. Of course, an individual firm will be more interested in maximizing its own profits than maximizing profits for the entire class.

\section{Conclusions}

To understand competition in pharmaceutical markets, it is important to understand how consumers respond to changes in copayments, both for the product in question and for its competitors. Previous estimates considered a copayment moving in unison with competitor copayment and found elasticity estimates of approximately -0.2 . However, this study controls for competitor copayment and finds consumers are considerably more sensitive to copayment.

Given that consumers are highly responsive to differential copayments, manufacturers have several strategic options. First, a manufacturer can offer a large rebate to insurers in order to be assigned a low copayment relative to competitors 15 Second, manufacturers can merge to increase their product offerings and thus their negotiating power. Indeed, the first-stage regression results show that firms with higher sales (of other products) have lower copayments. Third, manufacturers can dampen the intensity of price competition by differentiating their products. This differentiation might be achieved through innovation or advertising. The results indicate that increases in advertising to physicians can offset increases in copayments, but such changes are costly.

Responsiveness to differential copayments has important implications for insurers as well. Private insurers can use differential copayment tiers to extract lower prices (net of rebates) from manufacturers. Private insurers have been tasked with performing this function for the U.S. government under the Medicare drug benefit. This approach is quite different from other federal programs,

\footnotetext{
${ }^{15}$ We do not observe the rebate paid by the manufacturer to the insurer in exchange for a lower copayment. Rebate data are not public. One approach to estimating rebates would be to infer rebates from the relationship between price and copayment. Another approach would be to estimate rebates by subtracting a given drug's sales as reported by a data vendor (such as Verispan which we use) from the company's reported sales net of rebates. Unfortunately, most companies do not report sales for individual drugs. Furthermore, rebates are often paid with a lag so a company's sales from year $t+1$ might be net of the rebates from year $t$.
} 
such as the veterans' drug benefit, in which government officials contract with manufacturers, and the senior medical benefit, in which government officials contract with physicians. Some argue that private insurers are ineffective in contracting with manufacturers so the government should do so Avorn, 2006 Slaughter, 2006), but this study provides evidence that private insurers can be effective. The estimates help explain why the Medicare drug benefit costs less than originally projected (Centers for Medicare and Medicaid Services, 2008). When an insurer can credibly say "no" to covering a given drug, as when there are close substitutes for the drug, the insurer can be an effective negotiator with a pharmaceutical manufacturer. For example, proton pump inhibitors are close substitutes for one another, so the insurer has leverage with the manufacturer. However, in classes with no close substitutes, a drug might command a high price, unless the buyer has governmental authority (Frank and Newhouse, 2008; Duggan and Scott Morton, 2010).

Given the sensitivity of demand to relative copayments, an insurer would potentially have even more leverage with manufacturers if it adds more tiers. Formularies with four tiers have been rare but are becoming more common. Whereas no employers surveyed had four or more copayment tiers in 2002, 13 percent did in 2010 (Kaiser Family Foundation, 2010). 


\section{References}

Angell, M., 2000. The Pharmaceutical Industry - To Whom is It Accountable? New England Journal of Medicine 342, 1902-1904.

Arcidiacono, P., Ellickson, P. B., Landry, P., Ridley, D. B., 2013. Pharmaceutical Followers. Duke University Working Paper.

Avorn, J., Mar. 2006. Part 'D' for 'Defective' - The Medicare Drug-Benefit Chaos. New England Journal of Medicine 354, 1339-1341.

Azoulay, P., 2002. Do Pharmaceutical Sales Respond to Scientific Evidence? Journal of Economics \& Management Strategy $11(4), 551-594$.

Baicker, K., Goldman, D., Jan. 2011. Patient Cost-Sharing and Healthcare Spending Growth. Journal of Economic Perspectives 25 (2), 47-68.

Berndt, E. R., Bui, L., Reiley, D. R., Urban, G. L., 1995. Information, Marketing, and Pricing in the U.S. Antiulcer Drug Market. American Economic Review 85 (2), 100-105.

Berndt, E. R., Pindyck, R. S., Azoulay, P., 2003. Consumption Externalities and Diffusion in Pharmaceutical Markets: Antiulcer Drugs. Journal of Industrial Economics 51 (2), 243-270.

Bradford, W. D., Kleit, A. N., Nietert, P. J., Steyer, T., McIlwain, T., Ornstein, S., 2006. How Direct-to-Consumer Television Advertising for Osteoarthritis Drugs Affects Physicians' Prescribing Behavior. Health Affairs 25 (5), 1371-1377.

Centers for Medicare and Medicaid Services, Jan. 2008. Medicare Prescription Drug Benefit's Projected Costs Continue To Drop. Press Release.

Chernew, M. E., Shah, M. R., Wegh, A., Rosenberg, S. N., Juster, I. A., Rosen, A. B., Sokol, M. C., Yu-Isenberg, K., Fendrick, A. M., 2008. Impact of Decreasing Copayments on Medication Adherence within a Disease Management Environment. Health Affairs 27 (1), 103-112. 
Ching, A. T., Ishihara, M., 2010. The Effects of Detailing on Prescribing Decisions under Quality Uncertainty. Quantitative Marketing and Economics 8 (2), 123-165.

Ching, A. T., Ishihara, M., 2012. Measuring the Informative and Persuasive Roles of Detailing on Prescribing Decisions. Management Science 58 (7), 1374-1387.

Chintagunta, P. K., Jiang, R., Jin, G. Z., Aug. 2009. Information, Learning, and Drug Diffusion: The Case of Cox-2 inhibitors. Quantitative Marketing and Economics 7 (4), 399-443.

Crawford, G. S., Shum, M., 2005. Uncertainty and Learning in Pharmaceutical Demand. Econometrica $73(4), 1137-1173$.

Donohue, J. M., Berndt, E. R., Rosenthal, M., Epstein, A. M., Frank, R. G., 2004. Effects of Pharmaceutical Promotion on Adherence to the Treatment Guidelines for Depression. Medical Care 42 (12), 1176-1185.

Dor, A., Encinosa, W., 2010. How Does Cost-Sharing Affect Drug Purchases? Insurance Regimes in the Private Market for Prescription Drugs. Journal of Economics \& Management Strategy $19(3), 545-574$.

Duggan, M., Scott Morton, F., 2010. The Effect of Medicare Part D on Pharmaceutical Prices and Utilization. American Economic Review 100 (1), 590-607.

Febbo, W., Feb. 2005. Managed Care Confidential. Pharmaceutical Executive.

Frank, R. G., Newhouse, J. P., 2008. Should Drug Prices Be Negotiated under Part D of Medicare? And If So, How? Health Affairs 27 (1), 33-43.

Galewitz, P., Dec. 2009. Seniors Often Reluctant to Switch Medicare Drug Plans. Kaiser Health News.

Gemmill, M. C., Costa-Font, J., McGuire, A., 2007. In Search of a Corrected Prescription Drug Elasticity Estimate: A Meta-Regression Approach. Health Economics 16 (6), 627-643. 
Goldman, D. P., Joyce, G. F., Escarce, J. J., Pace, J. E., Solomon, M. D., Laouri, M., Landsman, P. B., Teutsch, S. M., 2004. Pharmacy Benefits and the Use of Drugs by the Chronically Ill. Journal of the America Medical Association 291 (19), 2344-2350.

Gönül, F. F., Carter, F., Petrova, E., Srinivasan, K., 2001. Promotion of Prescription Drugs and Its Impact on Physicians' Choice Behavior. Journal of Marketing 65 (3), 79-90.

Gury, M., Feb. 2003. IMS Reports 8 Percent Constant Dollar Growth in 2002. Audited Global Pharmaceutical Sales to $\$ 400.6$ Billion. IMS Health.

Hensley, S., Aug. 2005. Drug Makers Seek To Transform Advertising. Wall Street Journal.

Iizuka, T., Jin, G. Z., Sep. 2005. The Effect of Prescription Drug Advertising on Doctor Visits. Journal of Economics \& Management Strategy 14 (3), 701-727.

Iizuka, T., Jin, G. Z., Dec. 2007. Direct-to-Consumer Advertising and Prescription Choice. Journal of Industrial Economics 55 (4), 771.

Jena, A. B., Calfee, J. E., Mansley, E. C., Philipson, T. J., 2009. 'Me-Too' Innovation in Pharmaceutical Markets. Forum for Health Economics \& Policy 12 (1), 1-19.

Joseph, K., Mantrala, M., 2009. A Model of the Role of Free Drug Samples in Physicians' Prescription Decisions. Marketing Letters 20 (1), 15-29.

Kahrilas, P. J., Falk, G. W., Johnson, D. A., Schmitt, C., Collins, D. W., Whipple, J., D'Amico, D., Hamelin, B., Joelsson, B., 2000. Esomeprazole Improves Healing and Symptom Resolution as Compared with Omeprazole in Reflux Oesophagitis Patients: A Randomized Controlled Ttrial. Alimentary Pharmacology and Therapeutics 1 (10), 1249-1258.

Kaiser Family Foundation, 2010. Prescription Drug Benefits. Employer Health Benefits 2010 Annual Survey, 143-152.

Ketcham, J. D., Simon, K. I., 2008. Medicare Part D's Effects on Elderly Drug Costs and Utilization. American Journal of Managed Care 14 (11), SP14-22. 
Lee, I.-H., Bloor, K., Hewitt, C., Maynard, A., Jan. 2012. The Effects of New Pricing and Copayment Schemes for Pharmaceuticals in South Korea. Health Policy 104 (1), 40-49.

Leibowitz, A., Manning, W. G., Newhouse, J. P., 1985. The Demand for Prescription Drugs as a Function of Cost-Sharing. Social Science and Medicine 21 (10), 1063-1069.

Lichtenberg, F. R., Philipson, T. J., 2002. The Dual Effects of Intellectual Property Regulations: Within- and Between-Patent Competition in the U.S. Pharmaceuticals Industry. Journal of Law and Economics 45 (2), 643-672.

Ling, D. C., Berndt, E. R., Kyle, M. K., 2002. Deregulating Direct-to-Consumer Marketing of Prescriptions Drugs: Effects of Prescription and Over-the-Counter Product Sales. Journal of Law and Economics 45, 691-723.

Manning, W. G., Newhouse, J. P., Duan, N., Keeler, E. B., Leibowitz, A., Jun. 1987. Health Insurance and the Demand for Medical Care: Evidence from a Randomized Experiment. American Economic Review 77 (3), 251-277.

Neslin, S., May 2001. ROI Analysis of Pharmaceutical Promotion (RAPP): An Independent Study. Slide presentation on Internet, 1-23.

Pharmaceutical Research and Manufacturers of America, Aug. 2005. PhRMA Guiding Principles Direct to Consumer Advertisements About Prescription Medicines.

Ridley, D. B., Axelsen, K. J., Jan. 2006. Impact of Medicaid Preferred Drug Lists on Therapeutic Adherence. PharmacoEconomics 24 Suppl 3, 65-78.

Rizzo, J. A., Apr. 1999. Advertising and Competition in the Ethical Pharmaceutical Industry: The Case of Antihypertensive Drugs. Journal of Law and Economics 42, 89-116.

Rosenthal, M. B., Berndt, E. R., Donohue, J. M., Epstein, A. M., Frank, R. G., 2003. Demand Effects of Recent Changes in Prescription Drug Promotion. The Henry J. Kaiser Family Foundation Paper 6085, 1-33.

Seman, J. J., Mar. 2003. In Search of Preferred Status. Pharmaceutical Executive. 
Slaughter, L. M., Jun. 2006. Medicare Part D - The Product of a Broken Process. New England Journal of Medicine 354, 2314-2315.

Venkataraman, S., Stremersch, S., Nov. 2007. The Debate on Influencing Doctors' Decisions: Are Drug Characteristics the Missing Link? Management Science 53 (11), 1688-1701.

Windmeijer, F., de Laat, E., Douven, R., Mot, E., 2006. Pharmaceutical Promotion and GP Prescription Behaviour. Health Economics 15 (1), 5-18.

Wosinska, M., Oct. 2002. Just What the Patient Ordered? Direct-to-Consumer Advertising and the Demand for Pharmaceutical Products. Harvard Business School Marketing Research Paper Number 02-04, 1-44.

Wroblewski, M. S., 2005. Pharmacy Benefit Managers: Ownership of Mail-Order Pharmacies. United States Federal Trade Commission. 